\title{
Proclus The NeOPLATONIST'S PROPOSALS ON EDUCATION: EPISTEMOLOGICAL PROLEGOMENA
}

\author{
Christos Ath. Terezis \\ University of Patras, Greece \\ terezis@upatras.gr
}

\begin{abstract}
This historical and systematic study discusses in the form of a reconstructive proposal the system of the general epistemological principles followed by the eclecticist Proclus, who attempts to organize and present questions on Education directly associated with Practical Reason. From the methodological point of view, the example emerged from his commentary on the Platonic dialogues Alcibiades I and Respublica for providing instruction is multidimensional and holistic and aims at a complete transformation of human personality. The foundation for any philosophical and political approach, as constantly stressed, is that human is a special and unique being that can be able to influence decisively the social status. Considering the content of the study, we are discussing, mainly from a historical point of view, the position and the purpose of Education in Late Hellenistic Period, as well as Proclus' contribution to the disciplines of Anthropology and Ethics, which are closely related to the objectives of Education. We complete the study with some further remarks with regard to the deepest meaning of Proclus' proposal and the possibility to implement it in these days. The above-mentioned are not presented as final conclusions, but as questions-inquiries, in order to propose an internally developing methodology for investigating.

KEYWORDS: Proclus, Education, Practical Reason, Alcibiades I, Respublica, Aristotle.
\end{abstract}

\section{Introduction}

The following study may generally be considered as a proposal for structuring a general epistemological principle system, the purpose of which is to compose inquiries dealing with questions about a strictly defined discipline. Specifically, our aim is to formulate a proposal with, as far as possible, universal criteria, and with the necessary, in our view, exemplifications on how Proclus the Neopla-

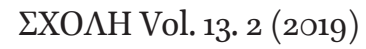

(C) Christos Terezis, 2019 www.nsu.ru/classics/schole DOI:10.25205/1995-4328-2019-13-2-486-502 
tonist forms systematically the subject matters included, in a broad sense, in Practical Reason. With regard to the specific content, we aim to follow a strictly organized methodology for presenting a part of his theory about Education and its relation to epistemological, ethical, political, aesthetic and metaphysical questions, namely we shall present a holistic view. However, before this presentation, we shall postulate some judgments, in the form of general principles, derived from his treatises. In particular, he considers that Education is a field to be approached as a scientific system. He deals with it as a broad discipline of theoretical principles and practical implementations, the purpose of which is constantly to shape a high quality human personality. What is more, since he believes that every person is a special and unique being with many mental and intellectual characteristics -which, depending on the circumstances, are utilized either in order or disorderly-, he considers that Education should not be univocally restricted by general or even particular principles about edification. It is to be in communication with those fields which compose systematic Anthropology.

In this perspective, Proclus gradually broadens his own theoretical direction: he places Education among the necessary for him goals to be achieved by both the philosophical thought and the political system that deal with Anthropology as founded on a teleological basis-prospect. On this ground, he does not explain human being in terms of a neutral Ontology or as enclosed in the intra-cosmic social conventions and occasional behaviors. ${ }^{1}$ He approaches it in a more flexible

\footnotetext{
${ }^{1}$ About Proclus' anthropological positions, cf. for instance, In Platonis Alcibiadem I, 1.1-9.21, where the rest of the disciplines are clearly involved. Cf. for instance the following extract, where Proclus mentions the subject matters that the Platonic dialogues deal

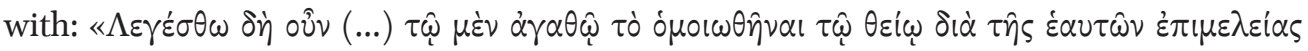

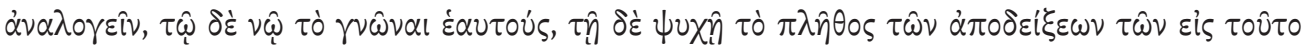

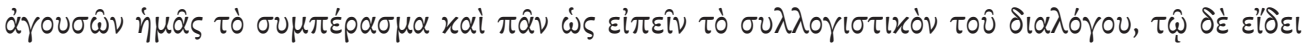

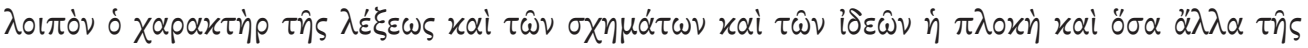

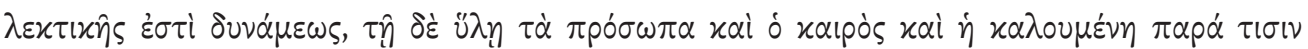

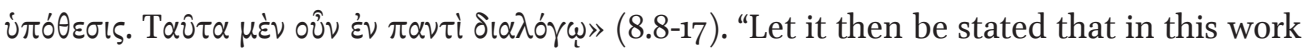
proportionate to the good is conformity to the divine, through the care of ourselves, to the intellect the knowledge of ourselves, to the soul the wealth of demonstrations leading us to this conclusion, and practically the whole syllogistic part of the dialogue; for the form there remains the style of the diction and the interweaving of the figures of speech, and of the literary forms, and what else belongs to stylistic ability; and for the matter the persons and the time is called by some the plot. Now these exist in every dialogue" [trans. W. O'Neil (1971) 7]. Cf. P. Bastid (1969) 365-382, and especially, 367, where he says: "Toute âme est à la fois un principe de vie et une chose vivante. Tout être en effet à qui advient une âme est nécessairement vivant. Et ce qui est privé d'âme est du même coup dénué de vie. Dés lors ou bien il doit sa vie à l'âme ou bien à un autre principe. Mais ceci est
} 
aspect, following the principles of the worldview that he adopts. It is remarkable that since the Socratic-Platonic tradition, Education was anthropologically realistic, for not only did it rely on general principles, but it intended to cultivate persons according to their own particular skills and capabilities. The goal was twofold: the universal laws related with human to be fulfilled and every individual to develop in his own subjective terms. ${ }^{2}$ And speaking of subjectivity here, we mean a person that will be gradually set free from pathogenies or negative passions, which either result from the person itself or are caused by external factors. That is to say, nominalist subject matters, which anthropologically are quite crucial, were not excluded, for they are associated to the recognition of the unique personal -and, possibly, bioorganic- character of every human being.

Nevertheless, approaching a question of Proclus' philosophical system is always quite difficult, for he is a philosopher-scientist-thinker who is interested in all the disciplines and actually follows their historical tradition. He is also confi-

impossible. Car tout participé ou bien se donne lui-même au participant, ou bien lui donne quelque chose de soi, et, s'il ne fournissait rien, il ne serait pas participé. Or, l'âme est participée par tout être auquel elle se rend présente, et on appellee animé ( $\left.\varepsilon_{\mu} \mu \psi v \times \vee v\right)$ cet être qui participe à l'âme. Si donc l'âme apporte la vie aux êtres animés, c'est qu'elle est ou bien vie ou bien seulement cicante, ou bien tous les deux ensemble. Mais si l'âme n'est que vivante sans être vie, elle sera composée de vie et de non-vie. La consequence est qu'elle ne peut se connaître ni se convertir vers elle-même. Car la connaissance est vie et le sujet connaissant vie en tant qu'il connait. S'il est donc dans l'âme quelque point sans vie, celui-ci ne détient pas en lui-même le pouvoir de connaître. Maintenant, si l'âme n'est que vie, elle ne pourra participer à la vie de l'intelligence". Cf. also, H. D. Saffrey (1990) 159-172. H. D. Saffrey also analyzes how Proclus founds his anthropological views on his theological positions, which, as a consistent Neoplatonist, are approached not in the terms of an emotional religiosity but in an ontological sense. Realism -which is fed by the metaphysical world- is once again explicitly established, for human being is considered to be a divine product capable of actualizing in his own terms great values, the content of which is considered as a priori existent in the metaphysical world.

${ }^{2}$ Plato's first dialogues, namely the Socratic ones, reveal a philosophical example about Education that insists on the individuality of those who receive instruction. For instance, in Lysis Socrates discourses with many young men in Athens, but he approaches each one of them in a special way, appropriate to his own character, axiologicalinterpretative criteria and the cultivation provided by the family, the social and educational environment. His goal is to establish in each and every one of them an internal culture with socio-political orientation. On the other hand, every young man constitutes the occasion for a specific approach of the same subject matter, the virtue of friendship and what sort of communication does it result in. Considering the question of friendship, this dialogue is completed with Phaedrus. Both of them may be combined with Aristotle's Ethica Eudemia and Ethica Nicomachea. 
dent that a discipline, despite its uniqueness, depends on and relates with the rest. In fact, he believes that all of them are included in all of them, each time in the appropriate way. ${ }^{3}$ In this sense, he avoids to elaborate a subject matter from just one perspective. Not only he frames it by many aspects but he also founds it on them in many modes. It could be easily contended that he is the thinker who attempted to form a single unified theory, namely to put all of his inquiries under universally applicable principles. He is a great lover of cohesive systems. On this basis, we shall also attempt to examine a special part of his theoretical analyses namely, Education-, in a way that could also be an example for the rest of the disciplines. Or, else, despite the fact that we intend to formulate a methodically structured proposal for approaching questions about how a particular field of Practical philosophy can be detected in Proclus, we indirectly aim at presenting broader theoretical proposals. Thus, during our inquiry a number of questions will be raised, with no definite answers, even though there will be a number of references to the primary sources and the secondary bibliography. The main objective of ours is to show the procedure to be followed when approaching one of Proclus' subject matters, relying on both history and systematicity, the synthesis of which is more than obvious in his treatises. In fact, it could be said that he is the greatest encyclopedist in Ancient Greek Philosophy, a lover of synthetic eclecticism. The general historical environment in which Proclus writes and teaches is also very important in our proposal. This is a synthetic project that has escaped the attention of academic interest, and we intend to support it with the appropriate epistemological frame, so that to reveal not only how history is combined with systematicity but also in what theoretical direction, which for every case is different. And, since the inquiry is related to both logical and communicative practice, it is possible that there would also be a proposal for the transformation of the political system, in a period of history at which the political system was mostly identified with monarchy.

Therefore, the goal of the following study-proposal is to identify, in the sense of general principles-directions, some of the views about Education and their philosophical foundations in the work of Proclus, who is actually not considered as an autonomous spiritual unit. The main source of ours will be the Neoplatonist

${ }^{3}$ Cf. for instance In Platonis Parmenidem 783.1-807.24 and Theologia Platonica, IV, 78.15-113-28. Note also that in Hypotyposis astronomicarum positionum, Proclus composes astronomy with mathematics and natural science. Scientifically speaking, the key in this text is astronomy. On the other hand, the same thing holds true in his comments on the Platonic Timaeus, where the key is natural science and mathematics, with the latter being, according to the Platonic tradition, the most important for theory and interpretation. Cf. Ann. Charles-Saget (1982) 187-320. 
Leader's treatise entitled In Platonis Alcibiadem I and, assistantly, his comments on Plato's Respublica. These are two extensive works, which can be also considered as specialized commentaries; thus, they are to be approached, once again, from an encyclopedic perspective, for they do not just present the arguments, nor do they just inform, but they synthesize them. Proclus constantly utilizes the past tradition -though not necessarily by following a typical succession of the positions presented by former thinkers about a question, mostly by Plato and Aristotle. Basically, our study can be placed in the context of History of Philosophy. Nevertheless, it broadly includes systematic subject matters as well, such as gnoseological, ethical, artistic-aesthetic, psychological, political and metaphysical. ${ }^{4}$ We believe that this wide perspective is necessary, for, as stressed before, Proclus suggests holistic approaches while dealing with philosophical questions and does not focus on just the particular discipline of which a subject matter is a part. He approaches it in many aspects, without ever ignoring that it is also a special one; that is to say, he keeps a balance, so as to preserve the original purpose and to explain it in many ways, raising questions that can cause a new elaboration in future.

Specifically, the plan of our inquiry may be structured as follows, in the sense of a reconstruction of the Neoplatonist Leader's argumentation, which will bring to the surface with the appropriate methodology his main positions about the example of Education that he intends to establish. The purpose of ours is to form a proposal to be discussed, which will both utilize the philosopher's texts taking into account their true theoretical context by following the scientific -and the reflective- choices of his and will include them into general categories, so as the meta-textual epistemological prospects to be established to be met as far as possible. In particular:

\section{Introducing Proclus as a philosopher}

No matter what the particular subject matter to be put under investigation is, the first thing to focus on is Proclus' contribution to the development of philosophical thought. Two are the theoretical aspects to be followed. First of all, one

\footnotetext{
${ }^{4}$ About the content of the first treatise, cf. the critical edition of A. Ph. Segonds, v. I and II (1985 and 1986) XXXIX-LII. About the content of the second treatise, cf. P. Bastid (1969) 53-65. This is the only detailed presentation of this work, with no elaboration though of the great political questions that Proclus raises or implies. A. J. Festugière (1970) has translated and commented on it in three volumes. This is a great study which gives value to this quite important commentary of Proclus and places it among the most important works of Neoplatonism. It should be also mentioned that he has separated the treatise in general sections and chapters with headings and subheadings, thus the reading of the work becomes easier.
} 
should take into account that he attempts to summarize -both by justifying and interpreting, which are two typical procedures of his worldview- the entire ancient Greek Ontology, Cosmology, Epistemology, Ethics, and Aesthetics. Secondly, the fact that he influenced the later philosophical systems, such as the medieval (Byzantine-Western) as well as the modern and contemporary theories, is also to be considered. ${ }^{5}$ Therefore, the crucial impact of his on the development of history of Philosophy has to be investigated, despite the fact that he lived in a period of time at which the social and political circumstances were not actually friendly, due to the fact that the time at which ancient Greek world hold a crucial historical role had come to an end.

By extension, it is necessary to raise the question of whether the Neoplatonist philosopher attempted to compose the fields of dialectics as a method but, basically, as a science, namely anything that can be considered as a part of Theoretical Reason, with moral and political Education, namely anything that Practical Reason involves. So, we are not only interested in his positions but also in the inner way in which they are structured, so as a pluralistic, coherent and complete system of knowledge to be formed. ${ }^{6}$ It could be actually argued that Proclus has generally turned method into a coherent theory or a strict epistemology, and this is a detail that needs to be stressed. Under one condition: he does not indent, as he, as a supporter of realism, declares, to put reality under a particular methodology. On the contrary: he attempts to find a way to adjust methodology in the subject matter.

\section{Education and its connections}

The questions to be raised and elaborated here have been dealt with by the scientific community in relation to other ancient Greek philosophers, such as Plato and Aristotle. ${ }^{7}$ Nevertheless, it is necessary to include them in the objectives of this study -no matter what its special content is-, that is to say, how they are structured in Proclus' treatises, after his reconstructions, which, due to the histor-

\footnotetext{
${ }^{5}$ About the impact of Proclus' work, cf. for instance P. Bastid (1971) 403-407. S. Breton (1973) 210-224. H Koch (1985) 438-454. J. Trouillard, (1982) 435-448.

${ }^{6}$ About the epistemological principles followed by Proclus, cf. L. Siorvanes (1966); S. Sambursky, (1965) 1-11.

${ }^{7}$ About Plato, cf. for instance R. Barrow (1976) and R. C. Lodge (1947). Cf. also W. Jaeger (1947) and (1971). In these two volumes, Jaeger makes an extensive historical and systematic presentation of the subject matter of Education in Plato, focusing on the Laws, a work of great importance in the history of Greek paideia, for, although "it contains most profound discussions of the state, of law, of morals, and of culture" puts at the center of attention the concept of Education, Plato's first and last word (1971, 213). About Aristotle, cf. for instance, R. A. Curren (2000).
} 
ical circumstances, are presented as necessary. Obviously, another thing to be taken into account is how mature -or, at least, different-are the scientific or interpretative judgements about a subject matter, in order, for instance, a theory to develop, or a cultural example to change, which is basically the foundation of the historical law.

\section{The position and the purpose of Education (and Edification at which it aims) in the late Hellenistic period}

A thing to be mentioned is that during the Hellenistic period Education -in a broad sense and not only in the sense of what takes place in the educational institutionsis mostly connected with religious or theological tendencies but also with sociopolitical ones. It relies on, it is founded on, it derives meaning from and it refers to Metaphysics, both the theoretical and the practical one, so the lessons to be taught or their special moral that results from a particular approach of them have an analogous content. During this period, social action as a true interference in historical events and political institutions as the legal protection of human values have remarkably declined, due to the Roman domination and the imperialism spread in the laws and the organization of the particular life aspects. During this historical period, strictly obligatory terms and conditions for both choices and actions were imposed. Thus, necessarily a person is characterized by an intense introversion and a constant reference to the divine, from which he attempts to derive the regulatory principles of his life. By means of experiences, thoughts and intuitional upward processes, he attempts to discover anything not provided by the collective institutions. In fact, indirectly, he thinks that these principles can function in a critical and reconstructive manner in relation to the current circumstances, a subversive condition that, due to the circumstances, can take place only in the world of consciousness or in the procedures caused by his experiences and emotions. ${ }^{8}$ Therefore, these two fields of human self are presented to be dominant in every discussion for any personal or relational subject matter.

By analogy, Education does not attempt in this case, at least obviously, to transform institutionally society or the political system; it is actually responsible to give morals to an individual and the personal relationships that he develops in the microcosm of his actions, with the prospect of generalization standing-by. Temporarily, it necessarily activates the principles of an edification of the selfhood, the tool -or the middle purpose- of which is self-knowledge, and the final goal is self-formation, in the sense of a personal entelechy. It could be actually

\footnotetext{
${ }^{8}$ About the religious actions of man during this period, cf. for instance P. Bouancé, (1955) 189-209• H. D. Saffrey (1990) 33-61.
} 
argued that at that time Education was explained in moderate terms with no clearly expressed goals that could be associated with the reformation of the productive forces and productive relations; it mostly appeared as an education process of the human consciousness in itself. As we will attempt to prove in our study, we have to keep in mind that Proclus proposes intensively radical, not only for his time, ideas about how collective life should generally be organized. These are ideas that also define how the political system and the institutions in which it must function should be structured, so that to complete particular purposes as an organized expression of the social participation ${ }^{9}$. Specifically, he is a strong exponent of democracy. The question here is whether he gives emphasis to the virtue of justice and whether he considers it both morally and politically. Or, else, whether he follows the Platonic Laws, a dialogue where the Practical Reason and its implementations have reached the highest point. Another question is whether he thinks of justice as the most important goal of human actions, which would give meaning and would add legitimacy to any form of them that is intentionally expressed and aims at freedom, which is considered to be the most important personal value. It goes without saying that it will be also investigated whether the Neoplatonist philosopher suggests a particular institutional function of justice in pathogenic situations and legal misconducts, that is, sentences for reversion to values that will be defined by experts as is stated in the Laws. ${ }^{10}$ Reference to Aristotle is quite necessary, since he had insisted on the great duty to be assigned to the legislators and the laws suggested by them, as expressions of a logical process independent of any sort of subjectivity. Also important is to mention that Aristotle focuses on the quality of the legislator whose responsibility is to regulate Education. ${ }^{\text {I }}$ Note that in ancient Greek tradition the legislator who is responsible for Education is considered to be the spirit of the city-state; therefore, it is important to investigate whether Proclus adopts this view. It is a question interesting for both History of Philosophy and Political Philosophy.

\section{Proclus' contribution to the systematic formation of philosophical Anthropology and Ethics of Late Hellenistic Period}

Attention should focus, here as well, on questions about former ancient Greek philosophers that have concerned academic interest. Scientifically, our next goal will be to show how Proclus approaches these questions, in order to explain and justify the elements of the development of the Ancient Greek civilization.

\footnotetext{
${ }^{9} \mathrm{Cf}$. In Platonis Rempublicam commentarii, I, 5.6-16.24.

${ }^{10}$ Cf. Leges, III, 681c-691d.

${ }^{11}$ Cf. Politica, III, 1287a.19-35 v. III, 1324b.3-1325a.33. Also, J. P. Anton (1996) 251-262.
} 
From the systematic point of view, it should be first of all mentioned that the disciplines of Anthropology and Ethics are not approached by the Neoplatonist philosopher independently. He believes that they should depend on Ontology. In his work, this field has a clear theological, or at least metaphysical, character, and includes those regulatory principles that define -or should define in terms of continuity- sensible world, both the natural and the historical ones. ${ }^{12}$ On this basis, everything that takes place in the metaphysical level, in terms of causality, and is reflected in the natural universe, should be an example and a regulation criterion for any human action as well. Therefore, man has to understand that he is a special reflection of the metaphysical archetypes and a positive microcosm, since actually the very first time that he was qualified for existing. Thus, the moral principles that he will decide to choose and apply, will constitute in a way his instrumental reason for his projection through his personal actions and the actualization of those ontological terms which contributed to the fact that he came into existence as a lining being. In addition, he will choose these principles having a prospect in his mind, that is, their purpose is to be transformed into a better person. So, all the disciplines that deal with human existence should be extensions of metaphysical Ontology and they should exemplify it by means of the personal initiatives of their bodies. Under these theoretical terms and conditions, realism dominates and does not allow idealism, in the sense of a thought independent from reality, to gain any autonomy.

In this context, Ethics is not exactly the discipline that describes how human becomes a better person, but how he reverses to the original terms of his own existence. Human had no original awareness of these terms, for he had been included into material pathogenic conditions, or for he lived in a pre-cultural state. On this basis, Proclus, having in mind their determination by metaphysical Ontology, considers the relationship between the disciplines of Anthropology and Ethics as a relation between an archetype and an image. And he actually presents this relation in a quite usual way for the Hellenistic period. Note, also, that he presented it in a systematic way, something that his predecessors did not do so intensively. ${ }^{13}$ One of our goals is to show the degree of his originality as well as

${ }^{12}$ Cf. Theologia Platonica, II, 3.5-30.26. J. Trouillard (1982) 235-248, where he says: «Proclos a bien des façons d'exprimer la transcendance de son Principe et celle de ses principes, puisque paradoxalement la transcendance et le caractère de "principe" sont jusqu'à un certain point communicables. Pour dire la transcendance il emploie les

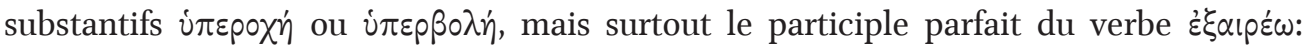

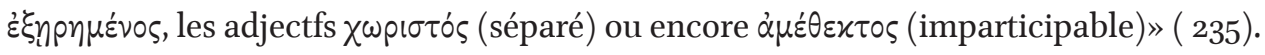

${ }^{13} \mathrm{Cf}$. In Platonis Timaeum commentaria, II, 214.16-227.3. For a perspective of this topic, cf. also P. Bastid (1969) 365-382 and 398-413. 
how he does it, keeping in mind, from the epistemological point of view, that the Hellenistic world was interested in the metaphysical foundations and perspectives of the questions that were under investigation. The questions to be raised here are how Proclus specializes this tendency and to what extent does he preserve rationality in research. ${ }^{14}$ This is a combination that requires a special approach of the factors associated, in order to define their capability of communicating with each other, or their successive appearance. Or, else, does human consciousness turn towards a mystical experience of the metaphysical plane, after rationality has reached the highest point?

\section{Research questions: the process in which the following subject matters about Education are presented in the two works of Proclus}

\section{The purpose of Education}

In his first introductory texts, Proclus contends that Education is one of the most decisive means to establish within human self the divine regulatory gnoseological, ethical and aesthetic- principles. The middle goals that result from this inclusion are for him human morality to be improved and his scientificepistemological capabilities related with field of the direct actionscommunications to be expanded. He stresses though that this expansion finally aims to discover the supreme archetypes of the natural world. Therefore, Theoretical and Practical Reasons lead to metaphysical Ontology, in order to derive their original, or at least prime, meaning. However, all these require knowing thyself as the source of all actions, which, due to this capability, has to be approached very carefully. One of these actions is also the special way in which the sensible world is approached. Thus, we become able to understand the greatest purpose of Education after we find out how it makes human being able to approach in a scientific way the natural world in the sense of theophany.

This approach, however, is not just scientifically interesting. In the context of edification formed, the first thing to detect is the general principles of Education according to Proclus and the special content of the educational interferences that in his view will make them true. After that and in relation to these principles, it is also important to detect the methodology in which the authentic for him orientation of Education will come into light, which is consequently considered by him as a specialized knowledge about human and things. It becomes clear that this inquiry will allow detecting whether Proclus knows what the particular is and

\footnotetext{
${ }^{14}$ Considering how rationalism is combined with mysticism, cf. Theologia Platonica II, 61.10-64.9. Cf, J. Trouillard (1982) 235-248. J. Bussianich (2000) 291-310.
} 
whether and in what degree he respects the realistic perspective of the world. ${ }^{15}$ Man is part of the natural world and an active being, two properties that neither the scientific nor any other kind of approaching his existence should ignore. Studying the universe, he also studies himself who is a part of its functions. Otherwise, he will result in an extreme idealism, for he will be trapped in his own intellectual procedures. And all of these under one more condition: if the natural world is a theophany, then, human being, as an organic part of it, participates in this property.

\section{Interaction between Education and Philosophy, in the light of getting to know natural environment}

At the next level of our analysis, we will have to show-prove the former discussion with specific text references, and with special explanations-categorizations: namely, despite the fact that the Neoplatonist philosopher denotes that he is going to deal with Education, he preserves the main principles of his system about a generalized Ontology-Cosmology, which is applied in other fields as well. He actually considers these principles regulatively important for any of his thoughts. Specifically:

a) The difference between the metaphysical and the natural worlds is by definition clear. ${ }^{16}$ Nevertheless,

b) The entire sensible world is the product of the supreme Principle, to which it will reverse due to an ontological necessity, when it will be completed after having totally assimilated the divine gifts. According to the general theoretical schemata of Neoplatonism, this is a teleological cosmological model. Furthermore, the natural world, which is subject to human perception, does not exclusively depend on its own terms and that is why a mechanistic cosmological model is excluded, which would be more appropriate for a solely material evolution. ${ }^{17}$

c) Natural world, however, could be also considered, at least under a particular prism, as the cause of the moral corruption, from which humans have to be protected or released. This sort of release will be accomplished by means of philosophical catharsis -note here also the Stoic apathy- and Education. According to Proclus, this does not result in an underestimation of nature but in changing the way it is used and explained according to what it is supposed to be as creation.

\footnotetext{
${ }^{15}$ Concerning the strictly educational content of Education, cf. In Platonis Alcibiadem I, 192.16-198.13.

${ }^{16}$ Cf. In Platonis Parmenidem, 815.8-833.23. Cf. J. Trouillard (1972) 69-109.

${ }^{17}$ Cf. In Platonis Timaeum commentaria, 258.12-274.32. For a detailed analyticalhistorical presentation and a deep interpretative reconstruction of the above-mentioned subject matter, one can get satisfying answers by studying A. Kojève (1973).
} 
This is important to be stressed, in order to preserve the given value of the metaphysical determination of the natural phenomena. Human is considered to be responsible for discovering the sources of the surrounding world and for exceeding a superficial explanation, which is strongly possible to result in hedonistic or exploitative goals. Human has to communicate-relate with the environment in conscious terms. Therefore, his morality and actions depend on his cognitive maturity, which develops gradually. Applied rationalism comes definitely to the fore as a suggestion, in order the meanings that result from the divine creation to be revealed and to be part of daily life.

Thus, the question is as follows: does Proclus introduce a theory of ecology and bioethics, in the broad sense? The main question, however, which is important for our next approaches, is whether he suggests human's autonomy or heteronomy in such a context of dependence, and under what interpretative and axiological criteria. This is a general existential question that relies on the distinction between freedom and determinism, concepts that require a special approach to be properly explained, as both the histories of philosophy and theology have proved. $^{18}$

\section{The impact of the current religious circumstances on the arisen educational model}

Based on what has been already discussed, a theory arises according to which human has to define as a regulatory principle his equalization with the divine and that this goal will be accomplished if he utilizes in the best way the elements of his own existence, that is, his intellectuality. Therefore, restricting his activity within the natural world is just relevant or turns into something important only if it becomes the starting point for ascending in the metaphysical world of the ontological integrity and norms. This sort of ascent is accomplished by means of an upward dialectics, which eliminates any element that changes human authenticity gradually and in reflexive and reconstructive modes. The question that should be investigated here as well, in addition to the former, is the following: does the

\footnotetext{
${ }^{18}$ It would be very interesting here to compare Proclus' comments on Alcibiades I with those on Timaeus, for in the former treatise the main question is about human as a personal being, while in the latter it is about the development of the natural world, in which human is included as an organism. Logical functions and their range also define the different levels of freedom between human and the natural world, though there is no support of the idea that the latter is subject to an absolute determinism. This is very crucial to keep in mind, for it is associated with teleology. The natural world is considered to be an expression of beauty, which is a quite special category -not only an aesthetic one-in Proclus' system. Beauty is the ontological core of nature, which expands by its exemplifications. For instance, cf. In Platonis Timaeum commentaria, 296.1-299.1.
} 
religiosity Proclus' thought restrict human freedom or does it actually contribute to the improvement of his personality? Is the philosopher involved with irrational mysticism or does he introduce a sort of rationality with specific boundaries, which could be developed by means of constant excesses into mysticism ${ }^{19}$ ? Taking into account the general spiritual tendencies of that historical period, it would be also interesting to investigate how Proclus theoretically uses the religious and theological texts of Chaldean Words, which are also interesting from the philosophical point of view..$^{20}$ Note that, since the beginning of the Hellenistic period, Greek civilization is influenced by the civilizations of the East and a dynamic eclecticism with broad synthetic reconstructions appears in many texts.

\section{Education and Dialectics}

This inquiry will transform the former theological perspective of the subject matters into a philosophical one. The historical point of view remains the basis: The impact of Plato's dialectics is obvious, although Proclus is not so intense as Plato, while elaborating questions related to skepticism and reflection. Plato gives priority to rationality and follows mysticism - not by putting them in an axiological hierarchy- while Proclus does the opposite or, at least, interchanges the relations ${ }^{21}$. The suggestions made in the new times are basically final -and, by extension, ethical- and do not actually raise questions. The Neoplatonist philosopher accepts the maieutic aspect of dialectics, an issue that will be elaborated in a following section of this study. Another question to deal with is whether Proclus adopts the Aristotelian version of dialectics and in what way does he use the Aristotelian and Stoic formal logic. For instance, the Neoplatonist Leader often refers to Aristotle's Analytica Priora et Posteriora and, sometimes, Categoriae; he is also

${ }^{19}$ Cf. Theologia Platonica, II, 64.11-65.26, where human's cognitive powers and their special relationships caused by their manifestation with reality, both the natural and the metaphysical, are briefly presented.

${ }^{20}$ Cf. Theologia Platonica, IV, 27-5-31.16 and 111.5-113.28. Cf. H. D. Saffrey (1990) 63-94, with great philological support. L. Brisson (200) 109-162. This is perhaps the most systematic study, which takes into consideration the entire former discussion on the subject matter, defining precisely and in detail how two traditions with different origin can be related.

${ }^{21}$ Cf. In Platonis Alcibiadem I, 169.11-181.2. About Plato's dialectics, it is to be said that it is defined by the special subject matter discussed each time. Despite the fact that the general principles are the same, it is differently applied in questions related to ethics and those associated with metaphysics. Thus, there are as many dialectics, in the sense of scientific methods, as the disciplines with which he deals, a detail that Proclus elaborates quite extensively. Either way, dialectics in their works has many perspectives. 
obviously influenced by Porphyry. ${ }^{22}$ Necessarily, one of our goals is to investigate Proclus' contribution to the development of dialectics and what its special direction is? Or, else, it is not just about what its historical origins are, which scientifically are quite important. Does he actually consider it a scientific system? In addition, does this dialectics set boundaries between theology and philosophy or does it somehow combine them? Does he or does he not form, here as well, a holistic example of knowledge ${ }^{23}$ ? In this case, both the downward and upward cognitive procedures that he follows should be investigated, as well as what are the necessary middle phases and how they are related one another.

\section{An anthropological example}

In this section, the requirements that define the goals of Education should be investigated, which, according to Proclus, are suggestions that rely on the structure of human nature, which in each case is exemplified. This is very important, for it establishes anthropological realism, which gnoseologically may not be easily approached. It is to be said that the Neoplatonist philosopher, by considering that the soul is superior to the body, contends that it produces in an authentic way the terms and conditions for the upward reference of human to God. Nevertheless, he does not adopt anthropological dualism, but only the axiological one, which is closely related to the question of virtues in Plato, Aristotle and the Stoics, although he adjusts it in his own system. And note that these are not just references but compositions. That is to say, he chooses a fertile eclecticism, which could actually be characterized as multiform encyclopedism. Nevertheless, it is to be stressed that Proclus here makes something quite innovative: he introduces a radical consideration of the body, since he does not eventually evaluate it as something evil ${ }^{24}$. Therefore, why does he raise it in the scale of the anthropological values? Does he utilize general statements or an exemplified argumentation or even a combination of these two in the context of a generalized Anthropology? Furthermore, does the Neoplatonic Leader aim, following Plato's model, at a spiritual idealism, or at least does he deal with it by using an advanced or moderated skepticism. Or, else, does he choose axioms or critical reason to be his bio-

\footnotetext{
${ }^{22}$ Cf. In Platonis Alcibiadem I, 95·34-96.3· 217.15-16· 247·3-4.

${ }^{23}$ For a complete approach, one should investigate the introduction of the first book of Theologia Platonica together with the comments on Alcibiades I. They are texts that present the general foundations and epistemological principles of Proclus, together with special elaborations, where the historical aspect of philosophy is combined with the systematical one.

${ }^{24}$ The subject matter is systematically elaborated in Proclus' comments on the Platonic Timaeus. Cf. for instance, III, 1.1-52.14.
} 
theoretical example? It is quite obvious that the answers to be given should take into account his theory about body and how it is defined by the general principles of Anthropology. Namely, in what priorities-hierarchies is it founded or to what is it equal. In practice: why gymnastics is an important lesson? Form the Platonic point of view, this lesson is considered crucial for the virtue of courage, which expresses a strong spirit in any condition that needs an intense reaction to deal with it. Provided that it goes together with music education, so that there is a balance in human nature. Does Proclus support this association, considering that he is the Leader of a School? In our view, the way in which he connects these two lessons results in an inquiry about whether he proposes an optimistic anthropological example.

\section{Further remarks}

1. According to the former discussion, we believe that we could also investigate, among other things, the following subject matters in the context of an implementation of the questions that have been raised: We are to examine the possibility of applying Proclus' theories on Education in modern times, since, first of all, he considers as a requirement for the constitution of the moral and political life human personality, which is the criterion for any educational process, and, secondly, he does not include his argumentation and reasoning in general regulative idealisms. Therefore, the question is as follows: does the Neoplatonist philosopher defend the value of a dynamically renewing collectivity and is he of the opinion that human's submission to uncritical social stereotypes should be ignored? On this ground, we could also compare his theory with other theoretical systems formed before and after him by modern thinkers. For instance, we believe that the similarities between Proclus -and mainly according to his comments on Respublica- and H. Marcuse's critical theory -at least in the form in which he expresses it in his treatise One-dimensional $\mathrm{Man}^{25}$ - should be discussed, the main axiological position of which is that an authentic real man denies to associate with the dominant system, which eliminates particularity and the good theoretically collectivity. This is the man who does not submit to indirect attempts of the political system for massification and holds an unreconciled attitude against strategies and compromises.

2. Taking into account that Proclus' suggestions are not orientated towards productivity, efficiency and quantity but towards to find the qualitative new and authentic, we could investigate to what extent he actually aims at bringing to the surface an ontology of the person and a philosophy of the subject by means of

\footnotetext{
${ }^{25}$ Cf. H. Marcuse (2006).
} 
introversion or self-reference, including practice and actions which follow a particular planning. The arising questions in this case are various: to what extent does he actually bring to the fore new tendencies concerning the status of social and political practice in late Hellenistic period? Does he eventually propose, even indirectly, a transformation of the political system or at least a formation of it in terms which would ensure a better institutional organization? In this context, does Proclus deal with the question faced by the modern and contemporary thinking about the relation between law and ethics? Or, else, is law a virtuous part of ethics ${ }^{26}$ ? For ancient Greek thought, the whole discussion is associated with the transformational goals of Education.

Furthermore, does he consider law in a political and moral sense and does he set it free from the customs of a pre-cultural society? In such studies, the link between law and ethics is to be investigated not only regarding the general principles but also, and rather extensively, its exemplifications. The question that needs further discussion is whether Proclus includes his philosophical positions on education into the three-aspect distinction on law suggested in many parts of his work: metaphysical law, rational law, institutional law. It is also necessary to examine -for reasons related with the development of his theoretical concernswhether his comments on Respublica complete the anthropological suggestions made in his comments on Alcibiades I. In a synthesis: whether and under what terms a moral person is able and desires to be a citizen. By extension, we have to prove the general position supported by academic community that the epistemological example suggested by him is a holistic one and that his work is rightly titled as a "system".

\section{REFERENCES}

Sources

Proclus (1971) In Platonis Alcibiadem I. Ed. and trans. by W. O'Neil, Proclus: Alcibiades I. The Hague.

Proclus (1968-1997) Theologia Platonica. Ed. and trans. by H. D. Saffrey and L. G. Westerink, Théologie platonicienne, 6 vol. Paris.

Proclus (1985) In Platonis Alcibiadem I. Ed. and trans. by A. Ph. Segonds, v.I and II, Sur le Premier Alcibiade de Platon. Paris.

Proclus (1970) In Platonis Rempublicam Commentarii. Ed. and trans. by A. J. Festugière, Commentaire sur la république, 3 vol. Paris.

Plato (1924) Laches. Ed. and trans. by W. R. M. Lamb, Laches, Protagoras, meno, Euthedemus. Cambridge.

Plato (1968) Leges. Ed. and trans. by E. des Places, Les Lois, III. Paris.

Proclus (1966-1968) In Platonis Timaeum commentaria. Ed. and trans. by A. J. Festugière, Commentaire sur le Timée, 5 vol. Paris.

\footnotetext{
${ }^{26}$ Cf. J. Habermas (1996).
} 
Proclus (1963) Institutio Theologia. Ed. and trans. by E. R. Dodds, The Elements of Theology, Oxford.

Aristotle (1960-1989) Politica, III. Ed. and trans. by J. Aubonnet, Aristote: Politique. Paris. Aristotle (1967) Topica. Ed. and trans. by J. Brunschwig, Aristote. Les Topiques. Paris.

Secondary literature

Anton, J. P. (1996) Categories and Experience: Essays on Aristotelian Themes. New York. Barrow, R. (1976) Plato and Education, London.

Bastid, P. (1969) Proclus et la crépuscule de la pensée greque. Paris.

Bastid, P. (1971) "Proclus principal propagateur du Néoplatonisme," in: AA.VV., Le Néoplatonisme. Paris: 403-407.

Bouancé, P. (1955) “Théurgie et léléstique néoplatoniciennes," Revue de l'histoire des religions 149, 189-209.

Breton, S. (1973) "Âme spinoziste, Âme néoplatonicienne," Revue philosophique de Louvain 71, 210-224.

Brisson, L. (2000) "La place des Oracles chaldaiques dans la Théologie Platonicienne," in: A. P. Segonds and C. Steel, ed. Proclus et la Théologie Platonicienne. Paris, 109-162.

Bussianich, J. (2000) "Mystical Theology and Spiritual Experience in Proclus' Platonic Theology," in: A. P. Segonds and C. Steel, ed. Proclus et la Théologie Platonicienne. Paris, 291-310.

Charles-Saget, Ann. (1982) L'architecture du divin. Paris.

Curren, R. A. (2000) Aristotle on the Necessity of Public Education, Rowman / Littlefield.

Habermas, J. (1996) Between Facts and Norms: Contributions to a discourse theory of law and democracy. Trans. by W. Rehg. Cambridge, Mass.

Jeager, W. (1947) Paideia. The Ideals of Greek Culture: In Search of the Divine Centre, v. II, G. Highet (trans.). Oxford.

Jeager, W. (1971) Paideia. The Ideals of Greek Culture: The Conflict of Cultural Ideals in the Age of Plato, v. III, G. Highet (trans.). Oxford / New York.

Koch, H. (1985) "Proclus als Quelle des Pseudo-Dionysius Areopagita in der Lehre von Bösen," Philologus 54, 438-454.

Kojève, A. (1973) Essai d'une histoire raisonnée de la philosophie païenne, III. Paris.

Lodge, R. C. (1947) Plato's Theory of Education, London.

Marcuse, H. (2006) One-dimensional Man. London.

Saffrey, H. D. (1990) Recherches sur le Néoplatonisme après Plotin. Paris.

Sambursky, S. (1965) "Plato and Proclus and the Limitations of Science," Journal of History of Philosophy 3, 1-11.

Siorvanes, L. (1966) Proclus Neoplatonic Philosopher and Science. Edinburgh.

Trouillard, J. (1972) L'Un et l'âme selon Proclos. Paris.

Trouillard, J. (1982) "Proclus et Spinoza," Revue Philosophique 172, 435-448.

Trouillard, J. (1982) La mystagogie de Proclos. Paris. 